\title{
PEMBERDAYAAN MASYARAKAT MELALUI PELATIHAN ERGO-ENTREPRENEURSHIP UNTUK MENGEMBANGKAN PENGETAHUAN DAN SIKAP KEWIRAUSAHAAN SERTA MENINGKATKAN PENDAPATAN PEDAGANG KULINER LOKAL DI DESA PELIATAN, UBUD, GIANYAR
}

\author{
${ }^{1}$ Pande Wayan Suarsa, ${ }^{2}$ I Made Sutajaya \\ ${ }^{1}$ Guru SMP Negeri 2 Payangan, Gianyar \\ 2Jurusan Pendidikan Biologi FMIPA \\ Undiksha, Singaraja \\ E-mail: madesutajaya@yahoo.co.id
}

\begin{abstract}
Abstrak
Tujuan penelitian adalah memberdayakan masyarakat melalui pelatihan ergoentrepreneurship untuk meningkatkan pengetahuan dan sikap kewirausahaan pedagang kuliner di Desa Peliatan. Metode yang digunakan adalah melalui quasi eksperimen yang dipadukan dengan pendekatan Sistemik, Holistik, Interdisipliner, dan Partisipatore (SHIP). Rancangan penelitian menggunakan posttest only group design (treatment by subject design). Kegiatan yang dilakukan diawali dengan identifikasi masalah, kemudian dibuat prioritas masalah dan selanjutnya dibuat rencana tindak (action plan). Rencana tindak ini digunakan sebagai intervensi penelitian berupa pelatihan kewirausahaan berbasis ergonomi yang disebut dengan istilah ergo-entrepreneurship. Variabel bebas adalah pemberdayaan masyarakat melalui pelatihan ergo-entrepreneurship. Variabel tergantung adalah (a) pengetahuan di bidang kewirausahaan dan (b) sikap kewirausahaan. Data yang diperoleh dianalisis secara deskriptif dengan mencari persentase perubahan dan dilanjutkan dengan uji beda $t$ paired test dengan taraf signifikansi $5 \%$ untuk menganalisis perbedaan pengetahuan dan sikap pedagang kuliner antara sebelum dan sesudah pelatihan. Hasil analisis data menunjukkan bahwa pengetahuan dan sikap pedagang kuliner berbeda bermakna antara sebelum dan sesudah pelatihan ergo-entrepreneurship $(p<0,05)$. Dalam hal ini terjadi peningkatan pengetahuan sebesar $21,18 \%$ dan sikap kewirausahaan meningkat sebesar $9,57 \%$. Dengan demikian dapat disimpulkan bahwa pemberdayaan masyarakat melalui pelatihan ergo-entrepreneurship dapat meningkatkan pengetahuan dan sikap kewirausahaan pedagang kuliner.
\end{abstract}

Kata Kunci: Pemberdayaan, Ergo-entrepreneurship, dan Kuliner.

\begin{abstract}
The research objective is to empower the community through ergoentrepreneurship training to increase entrepreneurial knowledge and attitudes of culinary merchant in Peliatan Village. The method used is through a quasiexperimental combined with Systemic, Holistic, Interdisciplinary, and Partisipatore
\end{abstract}


(SHIP) approach. The study design used a post-test only group design (treatment by subject design). Activities undertaken beginning with problem identification, priority issues and then made hereafter devised action plan. This action plan is used as an intervention in the form of research-based entrepreneurial training ergonomics and is called ergo-entrepreneurship. Independent variable is community empowerment through training ergo-entrepreneurship. Dependent variables are (a) knowledge in the field of entrepreneurship and (b) an entrepreneurial attitude. Data were analyzed descriptively by finding the percentage change followed by paired t test at the $5 \%$ significance level to analysis different of knowledge and entrepreneur attitude before and after training. The data analyzed shown that knowledge and entrepreneur attitude significant different before and after training $(p<0.05)$. There were increase of knowledge about $21.18 \%$ and entrepreneur attitude about $9.57 \%$. Therefore, it could be concluded that community empowerment through training ergo-entrepreneurship increase knowledge and entrepreneur attitude of culinary merchant.

Keywords: Empowerment, Ergo-entrepreneurship, and Culinary.

\section{PENDAHULUAN}

Kondisi ekonomi masyarakat Desa Peliatan mulai tahun 2002 tampaknya mengalami penurunan dilihat dari pendapatan mayarakat per hari. Dalam hal ini Sutajaya \& Ristiati (2011) melaporkan bahwa pendapatan masyarakat ketika menjadi pematung adalah sebesar Rp. 150.000,- per hari dan setelah berubah profesi menjadi buruh bangunan menjadi Rp. 50.000,per hari. Itu terjadi sebagai akibat terpuruknya usaha dalam bidang pariwisata sebagai dampak dari Bom Bali pada saat itu. Itu terjadi karena masyarakat di Desa Peliatan lebih dominan menggantungkan nasibnya di bidang pariwisata (RPJM, 2011). Kondisi tersebut semakin diperparah oleh melambungnya harga sembako di pasaran. Dengan demikian dapat dikatakan bahwa perekonomian di Desa Peliatan mengalami goncangan yang sangat serius dan memerlukan penanggulangan sesegera mungkin agar tidak menimbulkan dampak yang lebih buruk lagi yang pada akhirnya akan dapat meningkatkan jumlah penduduk miskin.

Permasalahan yang dapat diidentifikasi pada pengembangan usaha ekonomi produktif atau usaha mikro masyarakat yang berkaiatn dengan seni, budaya, dan kuliner adalah; (a) kurangnya modal usaha; (b) ketidakberanian masyarakat untuk memanfaatkan pinjaman di Bank sebagai modal usaha; (c) kurangnya pengetahuan dan pengalaman masyarakat tentang kewirausahaan; (d) kurangnya aset dan akses usaha; (e) mutu hasil olahan yang relatif rendah; (f) bahan baku untuk kerajinanan tergolong mahal karena didatangkan dari luar kota bahkan dari luar Pulau Bali; dan (e) sulitnya pemasaran produk yang dihasilkan; serta (f) minimnya fasilitator yang dapat membantu masyarakat untuk memfasilitasi usaha pemasaran dan pengadaan bahan baku (PLPBK, 2011). Hal ini mengakibatkan banyak usaha mikro yang tidak mampu berkembang dan terancam bangkrut.

Padahal Desa Peliatan memiliki berbagai potensi ekonomi yang cukup

Jurnal IImu Sosial dan Humaniora|610 
handal dan dapat mendatangkan penghasilan yang memadai. Misalnya dari hasil uji coba usaha kuliner khas Desa Peliatan yang dibuka di Alun-alun depan Puri Peliatan selama 11 hari dari tanggal 4 s.d. 15 Maret 2012 diperoleh data: (a) penghasilan pedagang mencapai 1,5 s.d. 2,3 juta selama kegiatan; (b) jumlah pelaku kuliner semakin meningkat yang semula hanya 9 pedagang meningkat menjadi 31 pedagang; (c) antusiasme masyarakat untuk mengunjungi tempat tersebut cukup tinggi, karena rerata kunjungan per hari kurang lebih 300 orang. Akan tetapi dengan semakin banyaknya para pendatang yang membuka usaha di Desa Peliatan membuat masyarakat Desa Peliatan semakin terdesak dan kehilangan peluang untuk usaha-usaha tertentu karena ketatnya persaingan ekonomi saat ini dan rendahnya pengetahuan masyarakat dalam bidang kewirausahaan.

Pemberdayaan

masyarakat merupakan strategi pembangunan. Dalam perspektif pembangunan ini, disadari betapa penting kapasitas manusia dalam upaya meningkatkan kemandirian dan kekuatan internal atas sumber daya materi dan nonmaterial (Muchtar, 2007). Potensi kuliner sesunguhnya adalah modal besar bagi masyarakat di Desa Peliatan, akan tetapi karena tersendat-sendatnya upaya pemasaran kuliner tersebut mengakibatkan banyak masyarakat yang ingin beralih ke usaha lain. Permasalahan mendasar inilah yang tampaknya dapat ditanggulangi melalui pemberdayaan masyarakat dengan pelatihan ergo-entrepreneurship. Dalam pelatihan tersebut ditekankan bahwa prinsip-prinsip ergonomi selalu dijadikan acuan di dalam memperbaiki kondisi kerja pada usaha kuliner baik pada proses pembuatan makanan maupuun saat menjajakan makanan tersebut. Hal itu dilakukan demi terwujudnya kuliner lokal yang layak jual dan sehat sehingga berpeluang untuk dikembangkan ke arah yang lebih maju di era global yang ditandai dengan persaingan yang semakin ketat dan keras.

\section{METODE}

Penelitian quasi experimental yang difokuskan pada pemberdayaan masyarakat melalui usaha kuliner lokal dipadukan dengan pendekatan sistemik, holistik, interdisipliner dan partisipatori (SHIP). Sistemik atau melalui pendekatan sistem artinya dimana semua faktor yang berada di dalam satu sistem dan diperkirakan dapat menimbulkan masalah harus ikut diperhitungkan sehingga tidak ada lagi masalah yang tertinggal atau munculnya masalah baru sebagai akibat dari keterkaitan sistem. Holistik artinya semua faktor atau sistem yang terkait atau diperkirakan terkait dengan masalah yang ada, haruslah dipecahkan secara proaktif dan menyeluruh. Interdisipliner artinya semua disiplin terkait harus dimanfaatkan, karena makin kompleksnya permasalahan yang ada diasumsikan tidak akan terpecahkan secara maksimal jika hanya dikaji melalui satu disiplin, sehingga perlu dilakukan pengkajian melalui lintas disiplin ilmu. Partisipatori artinya semua orang yang terlibat dalam pemecahan masalah tersebut harus dilibatkan sejak awal secara maksimal agar dapat diwujudkan mekanisme kerja yang kondusif dan diperoleh produk

Jurnal IImu Sosial dan Humaniora |611 
yang berkualitas sesuai dengan tuntutan jaman (Manuaba, 2008).

Penelitian quasi experimental menggunakan rancangan posttest only group design (treatment by subjects design), dengan pola dasar sebagai berikut (Colton, 2007).

$$
\text { P ---- RS------ -----(-)-----01------WOP----- -----(p)------02 }
$$

Gambar 01. Bagan Rancangan Penelitian

Keterangan:

$\mathrm{P} \quad$ : populasi berupa pedagang kuliner lokal

RS : sampel dipilih secara random

01 : pendataan sebelum dilakukan pemberdayaan masyarakat melalui pelatihan ergoentrepreneurship (Periode I)

$\mathrm{O} 2$ : pendataan sesudah dilakukan pemberdayaan masyarakat melalui pelatihan ergoentrepreneurship (Periode II)

(-) : kondisi kuliner sebelum dilakukan pemberdayaan

Subjek penelitian adalah pedagang kuliner yang ada di Desa Peliatan, Kecamatan Ubud, Kabupaten Gianyar, Provinsi Bali. Objek penelitian adalah sarana dan prasarana atau infrastruktur yang digunakan untuk usaha kuliner. Populasi target pada penelitian ini adalah semua pedagang kuliner yang ada di Desa Peliatan. Populasi terjangkau adalah pedagang kuliner khas Desa Peliatan yang memenuhi kriteria inklusi yang berjumlah 39 orang. Sampel pada penelitian ini adalah pedagang kuliner khas Desa Peliatan yang terpilih secara acak sederhana (simple random) dalam penentuan jumlah sampel dan dilibatkan secara penuh pada penelitian ini.

Untuk menghindari adanya bias yang disebabkan oleh karakterisistik masyarakat melalui pelatihan ergo-entrepreneurship

(p) : kondisi kuliner setelah dilakukan pemberdayaan masyarakat melalui pelatihan ergoentrepreneurship

WOP : washing out period atau proses penghilangan efek sebelum diberi perlakuan yang diberikan selama satu minggu sekaligus sebagai proses adaptasi terhadap perlakuan yang diberikan.

subjek dibuat kriteria untuk membatasi jumlah subjek yang bisa dilibatkan dalam penelitian ini. Kriteria inklusi dalam penentuan sampel adalah: (a) berbadan sehat; (b) bersedia sebagai subjek penelitian; dan (c) tidak memiliki cacat tubuh. Di samping itu juga ditentukan kriteria eksklusi dengan ketentuan: (a) berdagang bukan sebagai pekerjaan pokok; dan (b) tidak siap dipekerjakan secara berkelompok dalam suatu tempat yang telah ditentukan. Kriteria drop out yang dipersyaratkan pada penelitian ini adalah: (a) tidak bekerja pada saat penelitian; (b) menderita sakit saat penelitian berlangsung; dan (c) karena alasan tertentu mengundurkan diri sebagai sampel

Jurnal IImu Sosial dan Humaniora |612 
Jumlah sampel yang dilibatkan dalam penelitian ini adalah sebanyak 15 orang pedagang kuliner yang dipilih secara acak bertingkat (multistage random sampling). Teknik penentuan besar sampel adalah: (a) mengacu kepada jumlah populasi terjangkau sebanyak 39 pedagang yang tersebar di sepuluh banjar yang ada di Desa Peliatan dibuat daftar namanya; (b) dari daftar nama tersebut dibuat proporsi sesuai dengan jumlah warga yang berkecimpung dalam bidang tersebut di masing-masing banjar; (c) setelah ditentukan persentase sampel tiap banjar, dilakukan pemilihan dengan teknik random sederhana (simple random) dengan cara undian; dan (d) dengan demikian akan terpilih 15 sampel pedagang kuliner yang tersebar di masing-masing banjar.

Variabel dalam penelitian ini adalah: (a) variabel bebasnya adalah pemberdayaan masyarakat melalui pelatihan ergo-entrepreneurship; (b) variabel tergantungnya adalah pengetahuan di bidang kewirausahaan berbasis ergonomi; dan (2) sikap kewirausahaan. Strategi analisis data yang digunakan pada penelitian ini adalah: (a) data kondisi subjek, karakteristik kuliner, dan kondisi lingkungan dianalaisis secara deskriptif; dan (b) data pengetahuan dan sikap kewirausahaan sebelum dan sesudah perlakuan dianalisis dengan uji t paired karena datanya berdistribusi normal pada taraf signifikansi $5 \%$ dan selanjutnya dilihat persentase perubahannya.

\section{HASIL DAN PEMBAHASAN}

Bertolak dari hasil analisis data tentang pengetahuan dan sikap pedagang kuliner antara sebelum dan sesudah pelatihan ergoentrepreneurship yang lebih menekankan kepada pendekatan partisipatori diperoleh hasil penelitian sebagai berikut.

Tabel 01. Kondisi Subjek yang Terlibat sebagai Sampel $(n=15)$

\begin{tabular}{|c|l|c|c|}
\hline No & \multicolumn{1}{|c|}{ Variabel } & Rerata & SB \\
\hline 1 & Umur Pedagang (tahun) & 45,53 & 8,01 \\
\hline 2 & Pengalaman Kerja (tahun) & 15,87 & 6,62 \\
\hline 3 & Pendapatan per hari (Rp.) & $397.333,33$ & $77.571,78$ \\
\hline 4 & Jumlah modal awal (Rp.) & $1.063 .333,3$ & $202.190,37$ \\
\hline
\end{tabular}

Tabel 02. Karakteristik Kuliner yang Dijajakan $(n=15)$

\begin{tabular}{|c|l|c|}
\hline No & \multicolumn{1}{|c|}{ Variabel } & Persentase \\
\hline 1 & Berupa makanan tradisional & $73,3 \%$ \\
\hline 2 & Makanan khas desa setempat & $40,0 \%$ \\
\hline 3 & Dimasak sendiri oleh pedagang & $73,3 \%$ \\
\hline 4 & Tidak menggunakan penyedap rasa & $46,7 \%$ \\
\hline 5 & Bahannya berasal dari pasar desa setempat & $86,7 \%$ \\
\hline 6 & Memasak langsung di tempat berjualan & $53,3 \%$ \\
\hline
\end{tabular}


Tabel 03 Kondisi Lingkungan di Sekitar Tempat Berjualan $(n=15)$

\begin{tabular}{|c|l|l|}
\hline No & \multicolumn{1}{|c|}{ Variabel } & \multicolumn{1}{|c|}{ Keterangan } \\
\hline 1 & Areal parkir seluas $15 \times 40 \mathrm{~m}$ & Cukup memadai \\
\hline 2 & $\begin{array}{l}\text { Ada tempat beristirahat berupa bale } \\
\text { sakenem }(6 \times 4 \mathrm{~m})\end{array}$ & Cukup nyaman untuk lesehan \\
\hline 3 & Akses menuju kuliner sangat lancar & Di pinggir jalan protokol \\
\hline 4 & Tempat menyimpan rombong/ meja & $\begin{array}{l}\text { Di gedung serba guna atau di } \\
\text { sekitar kantor desa }\end{array}$ \\
\hline 5 & Kebersihan areal & $\begin{array}{l}\text { Terjamin, karena ada petugas } \\
\text { kebersihan }\end{array}$ \\
\hline 6 & Pengaturan parkir & $\begin{array}{l}\text { Dilakukan oleh seorang tukang } \\
\text { parkir }\end{array}$ \\
\hline 7 & Keberadaan lalat, kecoa, dan tikus & $\begin{array}{l}\text { Diatasi dengan menutup atau } \\
\text { menggunakan rak kaca }\end{array}$ \\
\hline 8 & Keberadaan debu terpaan angin & $\begin{array}{l}\text { Diatasi dengan menyiram areal } \\
\text { sebelum kuliner dibuka }\end{array}$ \\
\hline 10 & Perpaan sinar matahari & $\begin{array}{l}\text { Diatasi dengan penambahan atap } \\
\text { pada rombong }\end{array}$ \\
\hline 11 & $\begin{array}{l}\text { Penggunaan detergen untuk mencuci } \\
\text { piring dan peralatan lainnya }\end{array}$ & $\begin{array}{l}\text { Diatasi dengan membuang limbah } \\
\text { di tempat yang jauh dari areal } \\
\text { kuliner }\end{array}$ \\
\hline 12 & $\begin{array}{l}\text { Dapat diminimalkan dengan } \\
\text { memanfaat inke beralaskan daun } \\
\text { pisang sebagai wadah makanan }\end{array}$ \\
\hline
\end{tabular}

Tabel 04. Hasil Uji Beda Pengetahuan dan Sikap Kewirausahaan Pedagang Kuliner antara Sebelum dan Sesudah Pelatihan $(n=15)$

\begin{tabular}{|c|l|c|c|c|c|c|c|}
\hline No & \multicolumn{1}{|c|}{ Variabel } & \multicolumn{2}{|c|}{ Periode I } & \multicolumn{2}{|c|}{$\begin{array}{c}\text { Periode II } \\
\text { (Sebelum Pelatihan) }\end{array}$} & $\begin{array}{c}\text { Nilai } \\
\text { (Sesudah Pelatihan) }\end{array}$ & $\begin{array}{c}\text { Nilai } \\
\mathrm{t}\end{array}$ \\
\hline 1 & Rerata & SB & Rerata & SB & & \\
\hline 2 & $\begin{array}{l}\text { Pengetahuan } \\
\text { pedagang }\end{array}$ & 48,78 & 6,09 & 59,11 & 4,45 & 6,052 & 0,0001 \\
\hline $\begin{array}{l}\text { Sikap } \\
\text { kewirausahaan } \\
\text { pedagang }\end{array}$ & 56,22 & 4,01 & 61,60 & 4,04 & 6,282 & 0,0001 \\
\hline
\end{tabular}

SB: Simpangan Baku 


\section{Karakteristik Kuliner}

Karakteristik kuliner yang ada di Desa Peliatan adalah: (a) menjajakan makanan tradisional dilakukan oleh $73,3 \%$ pedagang; (b) menjajakan makanan khas desa setempat dilakukan oleh 40,0\% pedagang; (c) memasak sendiri makanan yang dijajakan dilakukan oleh 73,3\%; (d) tidak menggunakan penyedap rasa dilakukan oleh 46,7\% pedagang; (e) menggunakan bahan baku dari pasar desa setempat dilakukan oleh 86,7\% pedagang; dan (f) memasak langsung di tempat berjualan dilakukan oleh 53,3\% pedagang. Dilihat dari persenase tersebut tampaknya kuliner di desa tersebut cenderung menjajakan makanan tradisional yang dibuat sendiri oleh pedagang dengan menggunakan bahan baku yang dibeli di pasar desa setempat. Kondisi tersebut tampaknya perlu dipertahankan agar makananmakan khas Bali tetap lestari dan semakin digemari oleh masyarakat. Di samping itu ditemukan bahwa hanya $46,7 \%$ saja yang tidak menggunakan penyedap rasa. Ditinjau dari unsur kesehatan tampaknya hal itu perlu ditanggulangi sesegera mungkin agar tidak menimbulkan dampak negatif terhadap kesehatan konsumen.

Makanan khas desa setempat yang dijajakan adalah topot, jaja kukus, tipat santok, betutu, daluman, cendol, loloh, tipat sate, tahu basa lalah, jukut mebejek, pesan celengis, pesan kakul, pesan lindung, bubuh basa nyuh, jaja giling-giling, dan lain-lain. Barang dagangan tersebut sangat khas dinilai dari cara pembuatannya, cara penyajiannya, dan bumbu yang digunakan. Kekhasan ini membuat para pelanggan wajib datang ke tempat tersebut karena di tempat lain tidak ditemukan makanan khas seperti itu. Kondisi inilah yang membuat para pedagang yakin bahwa dagangannya akan dicari oleh para pelanggan.

Keunikan makanan tersebut tentu berpotensi untuk dikembangkan dan dipasarkan secara lebih luas dan dapat memotivasi para pedagang untuk berwirausaha lebih lanjut. Sutajaya \& Gunamantha (2014) melaporkan bahwa melalui pemberdayaan pedagang kuliner mengakibatkan: (a) munculnya semangat baru bagi pedagang kuliner yang sebelumnya sempat tidak percaya diri untuk berbisnis di bidang tersebut; (b) munculnya kelompok pedagang kuliner yang siap berjualan sesuai dengan aturan yang telah ditetapkan oleh desa; (c) berhasil dibuat tenda knock down yang bisa dibongkar pasang, karena areal yang dimanfaatkan untuk usaha kuliner tersebut paginya digunakan sebagai tempat parkir; dan (d) usaha kuliner yang dibangun tersebut menjadi sumber penghasilan baru bagi pihak desa.

\section{Kondisi Lingkungan di Areal Kuliner}

Kondisi lingkungan di areal kuliner sangat menentukan keberlanjutan kuliner tersebut. Dalam hal ini ditemukan bahwa: (a) areal parkir seluas $15 \times 40 \mathrm{~m}$ dinilai cukup memadai untuk 100 s.d. 150 orang pengunjung; (b) tersedianya tempat beristirahat berupa bale sakenem (6x4m) diniilai cukup nyaman untuk lesehan atau sekadar untuk tempat duduk saat konsumen menikmati hidangan yang disajikan; (c) akses menuju kuliner sangat lancar karena lokasinya berada di pinggir jalan protocol; (d) tempat menyimpan 
rombong atau meja dimanfaatkan gedung serba guna atau di sekitar kantor desa sehingga sangat efektif dan efisien saat menyimpan peralatan tersebut; (e) kebersihan areal sangat terjamin, karena ada petugas kebersihan yang selalu menjaga kebersihan di areal tersebut; (f) pengaturan parkir juga dinilai cukup rapi, karena sudah dipekerjakan seorang tukang parkir yang cukup handal; (g) keberadaan lalat, kecoa, dan tikus yang sering mengintai makanan yang dijajakan diatasi dengan cara menutup atau menggunakan rak kaca; (h) keberadaan debu terpaan angin

diatasi dengan menyiram areal sebelum kuliner dibuka; (i) terpaan sinar matahari diatasi dengan penambahan atap pada rombong; (j) penanganan limbah kuliner diatasi dengan membuang limbah di tempat yang jauh dari areal kuliner; (k) penggunaan detergen untuk mencuci piring dan peralatan lainnya dapat diminimalkan dengan memanfaat inke beralaskan daun pisang sebagai wadah makanan; dan (I) dengan lokasi kuliner di sekitar Gedung Serba Guna tampaknya sangat strategis karena mudah dijangkau dari segala penjuru dan jika ada kegiatan di gedung tersebut akan menambah jumlah pembeli.

Kondisi lingkungan tersebut dinilai sangat memadai untuk pengembangan kuliner ke arah yang lebih maju dan lebih mandiri. Dalam hal ini Adnyana (2013) melaporkan bahwa kondisi lingkungan yang dipertimbangkan di dalam beraktivitas adalah suhu kering, suhu basah, dan kelembaban relatif yang dipengaruhi oleh efek termal suatu peralatan. Suhu kering yang menyertai para tukang banten saat beraktivitas adalah 29 s.d. $31^{\circ} \mathrm{C}$ dan suhu basahnya adalah 27 s.d $29^{\circ} \mathrm{C}$ dengan kelembaban relatif 75 s.d $85 \%$. Kondisi lingkungan tersebut dinilai nyaman untuk beraktivitas sehingga tidak mengganggu produktivitas pekerja. Sutarja (2012) melaporkan bahwa kenyamanan termal atau fisik lingkungan di tempat beraktivitas dipengaruhi oleh temperatur, kelembaban relatif, kecepatan angin, pencahayaan, dan kebisingan. Dalam hal ini ditemukan bahwa temperatur di tempat kerja berkisar antara 26,5 s.d. $31^{\circ} \mathrm{C}$, kelembaban relatif berkisar antara 63 s.d $75 \%$, dan kecepatan angin antara 0,03 s.d. 0,15 m per detik. Kondisi lingkungan dengan rentangan tersebut dinilai nyaman untuk beraktivitas.

Di samping itu kondisi lingkungan biologis yang dinilai dari keberadaan lalat, kecoa, dan tikus juga harus diperhatikan, karena dapat mengganggu kesehatan pembeli atau dapat memunculkan kesan kumuh. Untuk itu disarankan agar tidak membuang limbah di sekitar areal kuliner yang dapat mengundang binatang tersebut. Kondisi lingkungan secara fisik seperti keberadaan debu yang dapat mengotori makanan juga perlu diperhatikan mengingat areal kuliner berada di pinggir jalan protocol. Hamburan debu akibat terpaan angin atau akibat laju kendaraan dapat mengotori makanan jika tidak ditanggulangi. Cara paling sederhana yang dilakukann oleh ara pedagang kuliner adalah dengan jalan menyiram areal kuliner sebelum kuliner dibuka. Ada juga yang sudah menggunakan rak kaca untuk menghindari paparan debu tersebut.

Kondisi lingkungan secara kimiawi dilihat dari penggunaan deterjen untuk mencuci piring dan peralatan kuliner. 
Hal ini ditanggulangi dengan menganjurkan kepada para pedagang untuk menggunakan inke beralaskan daun pisang sebagai wadah makanan, sehingga penggunaan deterjen untuk mencuci piring bisa diminimalkan. Pemanfaatan bahan penyedap untuk menyedapkan rasa makanan juga termasuk kondisi lingkungan kimiawi yang dapat mengganggu kesehatan pembeli. Hal ini ditanggulangi dengan sosialisasi bahaya yang ditimbulkan oleh bahan penyedap yang mengandung monosodium glutamat (MSG) tersebut.

\section{Pengetahuan Pedagang Kuliner}

Pada penelitian ini ditemukan bahwa terjadi peningkatan pengetahuan pedagang kuliner secara bermakna sebesar $21,18 \%$ antara sebelum dan sesudah pelatihan ergoentrepreneurship $(p<0,05)$. Itu bisa terjadi karena selama pelatihan disosialisasikan prinsip-prinsip ergonomi yang relevan untuk diaplikasikan di lapangan dan dipadukan dengan prinsip-prinsip kewirausahaan yang dapat memotivasi pedagang kuliner untuk mengembangkan usahanya.

Di samping itu para pedagang secara partisipatori dan proaktif berusaha untuk mengetahui berbagai hal yang dapat memajukan kulinernya. Mereka sering berdiskusi dengan teman sejawat, para pengunjung atau pembeli, dan masyarakat yang mempunyai pengalaman di bidang kuliner dan kewirausahaan. Konsep ergoentrepreneurship yang sering didiskusikan dengan para pedagang, tokoh masyarakat, dan aparat desa ternyata cukup memadai digunakan sebagai acuan di dalam menunjang pengetahuan pedagang pada khususnya dan pengetahuan masyarakat pada umumnya. Bahasa dan petunjuk yang sederhana yang tersurat di dalam pedoman tersebut cukup menggugah rasa ingin tahu para pedagang khususnya yang berkaitan dengan upaya peningkatan usaha kuliner yang sedang digeluti.

Anonim (2015) menyatakan bahwa ergo-enterpreneur merupakan program yang user friendly dan khusus dikembangkan untuk perusahaan konstruksi dan disesuaikan dengan filosofi kerja seseorang di suatu perusahaan. Pengguna menemukan dengan cepat solusinya melalui program yang diaplikasikan, yang merupakan pendekatan partisipatori dan biasa diterapkan di tempat kerja.

Khairani (2015) melaporkan bahawa bahwa determinasi (R2) pengetahuan kewirausahaan dan kemandirian pribadi mempengaruhi kinerja usaha. Dari pengujian secara parsial (uji t) variabel pengetahuan kewirausahaan tidak berpengaruh positif terhadap kinerja usaha namun variabel kemandirian pribadi memiliki pengaruh positif terhadap kinerja usaha. Liasari (2013) melaporkan bahwa berdasarkan hasil analisis data, diketahui bahwa pengetahuan kewirausahaan, kemandirian, dan minat berwirausaha termasuk dalam kategori tinggi. Diketahui juga, bahwa pengetahuan kewirausahaan dan kemandirian berpengaruh positif terhadap minat berwirausaha, baik secara parsial maupun simultan.

Yuliyaningsih, dkk. (2013) melaporkan bahwa (1) terdapat hubungan positif dan signifikan antara pengetahuan kewirausahaan dengan 
minat berwirausaha, (2) terdapat hubungan negatif dan tidak signifikan antara persepsi peluang kerja di bidang akuntansi dengan minat berwirausaha, (3) terdapat hubungan positif dan signifikan antara pengetahuan kewirausahaan dengan minat berwirausaha serta terdapat hubungan negatif dan signifikan antara persepsi peluang kerja di bidang akuntansi dengan minat berwirausaha. Pengetahuan kewirausahaan memiliki pengaruh yang lebih tinggi terhadap minat berwirausaha siswa dibanding persepsi peluang kerja di bidang akuntansi.

Nursito, dkk. (2013) melaporkan bahwa pendidikan kewirausahaan diterima dan membentuk pengetahuan kewirausahaan mahasiswa berpengaruh secara positif dan signifikan terhadap intense kewirausahaan mahasiswa. Hal ini dapat dilihat dari nilai koefisien pendidikan kewirausahaan yaitu 0,376 , $t=4,530$ dengan nilai $p=0,001(p$, $0,05)$. Selain pendidikan kewirausahaan, intense kewirausahaan mahasiswa juga dipengaruhi oleh faktor internal dalam diri mahasiswa, yaitu efikasi diri. Hal ini ditunjukkan oleh hasil analisis yang memberikan hasil nilai koefisien efikasi diri adalah 0,425, $\mathrm{t}=4,832$ dengan nilai $p=0,001(p<0,05)$. Selanjutnya, interaksi dua faktor tersebut yaitu pendidikan kewirausahaan dan efikasi diri, juga berpengaruh secara positif dan signifikan terhadap intense kewirausahaan mahasiswa. Pengaruh interaksi tersebut dapat dilihat dari nilai koefisien interaksi antara pendidikan kewirausahaan dengan efikasi diri adalah $0,120, t=2,921$ dengan nilai $p=$ $0,004(p<0,05)$.

\section{Sikap Kewirausahaan}

Pada penelitian ini ditemukan bahwa terjadi peningkatan yang signifikan sikap kewirausahaan pedagang kuliner sebesar 9,57\% antara sebelum dan sesudah pelatihan ergoentrepreneurship $\quad(p<0,05) . \quad$ Ini menandakan bahwa melalui pelatihan tersebut para pedagang kuliner semakin termotivasi untuk mengembangkan usahanya. Di samping itu muncul keberanian untuk berwirausaha. Dalam hal ini Sutajaya \& Gunamantha (2014) melaporkan bahwa terjadi peningkatan sikap kewirausahaan dilihat dari indikator: (a) produk kuliner hanya dipasarkan di areal terbatas (22,2\%); (b) usaha mencermati harga pasar $(11,1 \%)$; (c) kepedulian dengan harga pasar $(38,9 \%) ; \quad$ (d) usaha meningkatkan kualitas produk (0\%); (e) kecenderungan berusaha meningkatkan jumlah produk yang dihasilkan $(66,7 \%)$; (f) usaha meningkatkan jumlah dan kualitas produk (33,3\%); (g) usaha memasarkan melalui pasar tradisional di tempat lain $(44,4 \%)$; (h) usaha memasarkan melalui pasar swalayan $(22,2 \%)$; (i) usaha untuk membuka toko kecil di kawasan wisata $(22,2 \%)$; (j) usaha memasarkan produk kuliner dengan harapan mendapat keuntungan yang lebih tinggi $(11,1 \%)$; (k) keberanian meminjam modal di LPD (27,8\%); (I) usaha mengikuti kursus-kursus kewirausahaan (22,2\%); (m) usaha memperluas area pemasaran produk $(22,2 \%)$; (n) usaha menawarkan produk kuliner melalui rekanan dalam bidang pemasaran (5,6\%); (o) usaha membeli produk kuliner dari pedagang lain yang produknya berkualitas $(27,8 \%) ; \quad(p)$ usaha memenangkan persaingan di pasaran $(16,7 \%)$; (q) usaha sebagai

Jurnal IImu Sosial dan Humaniora |618 
penghasil produk sekaligus penjual (5,6\%); (r) melakukan diskusi dengan teman seprofesi $(11,1 \%)$; (s) menjalin kerjasama dengan kelompok-kelompok pedagang lainnya (11,1\%); dan (t) usaha memperluas pemasaran ke pasar-pasar swalayan, hotel, restoran, dan pihak lain (16,7\%).

Sutajaya \& Gunamantha (2014) juga melaporkan bahwa pelatihan yang dilakukan oleh dua orang pakar kuliner yang sekaligus pakar ekonomi ternyata dapat mengubah sikap kewirausahaan secara bermakna dimana terjadi peningkatan skor sikap kewirausahaan sebesar 41,59\%. Ini menunjukkan bahwa para pedagang kuliner mulai termotivasi untuk menggeluti bisnis tersebut. Di sisi lain tampak mereka semakin berani untuk menambah modal usaha dengan harapan agar bisa ditingkatkan kuantitas produk. Upaya pemasaran melalui cara lain, selain di areal yang disediakan pihak desa juga mulai tampak, karena 7 orang pedagang sudah mulai memasang iklan bahwa mereka menerima pesanan.

Seirama dengan peningkatan sikap kewirausahaan tersebut diyakini berdampak terhadap produktivitas pedagang. Itu bisa terjadi karena dengan semangat kewirausahaan yang tinggi tentu akan berkorelasi positif terhadap peningkatan produk yang dijual dan pada akhirnya omset penjualan akan meningkat. Ini tentu berdampak positif terhadap peningkatan produktivitas kerja pedagang kuliner. Hal yang sama juga dilaporkan oleh: (1) Sudiajeng (2010) melaporkan bahwa pemberdayaan pekerja melalui intervensi ergonomi pada organisasi dan stasiun kerja dapat meningkatkan kinerja bengkel kayu dilihat dari peningkatan produktivitas sebesar

$87,50 \%$,

(2) Suardana

(2012)

melaporkan bahwa pendekatan ergonomi dalam perancangan arsitektur meningkatkan kinerja pengguna bangunan dilihat dari peningkatan ketelitian kerja sebesar $87,2 \%$ dan konstansi kerja sebesar 15,79\%, (3) Wijaya (2012) melaporkan bahwa penerapan manajemen kinerja klinik berbasis Tri Hita Karana sebagai suatu pemberdayaan terhadap pekerja dapat meningkatkan kualitas kerja perawat dan bidan di rumah sakit umum Bangli sebesar 43\%, dan (4) Purnamawati (2013) melaporkan bahwa pemberdayaan tukang benten melalui intervensi ergonomi dapat meningkatkan efisiensi kerja tukang banten ngaben di Kota Denpasar, dilihat dari peningkatan produktivitas sebesar $78 \%$.

\section{PENUTUP}

Bertolak dari hasil analisis dan pembahasan yang dikaji berdasarkan literatur yang relevan dapat disimpulkan sebagai berikut: (1) Strategi pemberdayaan masyarakat melalui pelatihan ergo-entrepreneurship cukup memadai dilakukan dilihat dari antusiasme pedagang kuliner untuk mengembangkan usahanya. (2) Pemberdayaan masyarakat melalui pelatihan ergo-entrepreneurship dapat meningkatkan secara bermakna pengetahuan pedagang kuliner lokal di bidang strategi kewirausahaan berbasis ergonomi sebesar $21,18 \%(p<0,05)$. (3) Pemberdayaan masyarakat melalui pelatihan ergo-entrepreneurship dapat meningkatkan secara bermakna sikap kewirausahaan pedagang kuliner lokal sebesar 9,57\% ( $p<0,05)$. Berdasarkan simpulan di atas, saran yang

Jurnal IImu Sosial dan Humaniora |619 
disampaikan dalam penelitian ini adalah sebagai berikut. (1) Kepada pedagang kuliner disarankan agar tetap menggunakan acuan ergoentrepreneurship dalam mengembangkan usahanya karena telah terbukti cukup relevan untuk diaplikasikan. (2) Kepada aparat desa disarankan agar tetap mengembangkan kuliner local sebagai salah satu ciri khas desa setempat. (3) Kepada dinas terkait hendaknya selalu memfasilitasi pengembangan kuliner di suatu daerah mengingat usaha tersebut sangat potensial untuk menopang kehidupan masyarakat.

\section{DAFTAR PUSTAKA}

Adnyana, I W.B. 2013. Aplikasi Synergy Ergo-Mechanical System Meningkatkan Kapasitas Kerja pada Pekerja Wanita dan Efisiensi Energi Bahan Bakar Alat Pengering pada Industri Sarana Banten di Blahbatuh Gianyar Bali. Disertasi. Program Pascasarjana Universitas Udayana Bali.

Amperaningrum \& Ichyaudin, 2009. Hakekat Kewirausahaan. [Cited 2012 September 10] Available From

http://adesyams.blogspot.com/200 9/09/hakekat-kewirausahaan.html

Anonim, 2009, Pemberdayaan Masyarakat dan Pembangunan Berkelanjutan [Cited 2012 March 29] Available at http://www.pemberdayaan.com/pe mbangunan/pemberdayaanmasyarakat-dan-pembangunanberkelanjutan.html.

Anonim, 2015. Ergo-Entrepreneur [Cited 2015, July 18] Available From http://www.quadram.lu/product de tails. php?id=25\&sub1=14\&lang=1.

Azadeh, A., Fam, M., Garakani,M.M. 2007. A Total Ergonomis Design Approach to Enhance the Productivity in A Complicated Control System. Journal of Information Technology. 6 (7): $1036-1042$.

Bakker, A.B., Schaufeli, W.B., Leiter, M.P. \& Taris, T.W. 2008. Work Engagement: An Emerging Concept in Occupational Health Psychology. Work and Strees Journal, Vol.22. No. 3., 187-200.

Bakker, A.B. \& Leiter, M.P. 2010. Where to Go from Here: Integration and Future Research on Work Engagement; In: Bakker, A.B. \& Leiter, M.P. Editor: Work Engagement, A Handbook of Essential Theory and Research. New York: Psychology Press.

Bakker, A.B. 2010. Engagement and Job Crafting: Engaged Employees Create Their Own Great Place to Work, In: Albrecht,S. Editor. Handbook of Employee Engagement Perspectives, Issues, Researches and Practices. USA: Edward Elgar.

Bakker, A.B. Albrecht, S.L. \& Leiter,M.P. 2011. Key Question Regarding Work Engagement, European Journal of Work and Organizational Psychology. 20 (1), 4-28

Fam, M., Azadeh, A., Azam, A. 2007. Modeling an Integrated Health, Safety, and Ergonomis Management System: Application to Power Plants. Journal of Res Health Sciences. Vol 7 (2): 1 - 10.

Jurnal IImu Sosial dan Humaniora |620 
Geriya. 2007. Konsep dan Strategi Revitalisasi Kearifan Lokal dalam Penataan Lingkungan Hidup di Bali. Denpasar: Universitas Udayana.

Khairani, Y. 2015. Pengaruh Pengetahuan Kewirausahaan dan Kemandirian Pribadi Terhadap Kinerja Usaha (Studi Kasus Pada Pengusaha Depot Air Minum Isi Ulang di Jalan Veteran Kec. Labuhan Deli Kab. Deli Serdang). [Cited 2015, July 18] Available at http://www.researchgate.net/public ation/48380144

Liasari,

K. 2013. Pengaruh

Pengetahuan Kewirausahaan dan Kemandirian Terhadap Minat Berwirausaha: Survey pada Mahasiswa Fakultas IImu Pendidikan Universitas Pendidikan Indonesia. Tesis. Universitas Pendidikan Indonesia.

Limerick, L.B. Straker, L., Pollock, C. Dennis, G., Leveritt, S., Johnson, S. 2007. Implementation of the Participative Ergonomis for Manual Tasks (PErforM) Programme at Four Australian Underground Coal Mines. International Journal of Industrial Ergonomis. Vol. 37, No. 2. February: $145-155$.

Manuaba, A. 2008. Membangun Bali atau Membangun di Bali. BaliHESG. Denpasar.

Muchtar, 2007. Pemberdayaan Masyarakat Melalui Program Pengembangan Distrik (Kajian Kebijakan dan Implementasinya di Provinsi Papua) Jurnal Penelitian dan Pengembangan Kesejahteraan Sosial. Vol.12.No.02, Mei-Agustus 2007.
Munaf, D.R., Suseno, T., Janu, R.I., Badar, A.M. 2008. Peran teknologi Tepat Guna untuk Masyarakat Daerah Perbatasan. Jurnal Sosioteknologi No. 13 Tahun 7, April.

Nursito, S., Julianto, A., Nugroho, S. 2013. Analisis Pengaruh Interaksi Pengetahuan Kewirausahaan dan Efikasi Diri terhadap Intensi Kewirausahaan. Jurnal Kiat BISNIS Volume 5 No. 2 Juni 2013.

PLPBK, 2011. Pengembangan Potensi Seni dan Budaya Melalui Penataan Lingkungan

Permukiman Berbasis Komunitas sebagai Upaya untuk Meningkatkan Peluang Kerja Bagi Warga Miskin di Desa Peliatan Ubud Gianyar Bali. PLPBK Desa Peliatan, Kecamatan Ubud. Kabupaten Gianyar.

RPJM, 2011, Rencana Pembangunan Jangka Menengah Desa (RPJMDES) Desa Peliatan Tahun 20112015. RPJM Desa Peliatan, Kec. Ubud. Kabupaten Gianyar.

Purnamawati, M.S.P. 2013. Intervensi Ergonomi Meningkatkan Efisiensi Pekerja pada Proses Pembuatan Banten Upacara Ngaben Pranawa di Kota Denpasar. Disertasi. Program Pascasarjana Universitas Udayana Bali.

Sarna, K. 2008. Pengembangan Bahan Ajar Biologi Berbasis Lokal Genius. Makalah disampaikan dalam Seminar Jurusan Pendidikan Biologi Undiksha, Singaraja.

Shimazu, A. Miyanaka,D.

Schaufeli,W.B. 2010. Work Engagement from A Culture Perspective: In: Albrecht,S. editor.

Jurnal IImu Sosial dan Humaniora |621 
Handbook of Employee Engagement Perspectives, Issue, Researches and Practices. USA: Edward Elgar

Suardana, I P.G.E. 2012. Pendekatan Ergonomi dalam Perancangan Arsitektur (Ergo-Arsitektur) Meningkatkan Kenyamanan dan Kinerja Pengguna. Disertasi. Program Pascasarjana Universitas Udayana Bali.

Sudiajeng, L. 2010. Intervensi Ergonomi pada Organisasi dan Stasiun Kerja Meniingkatkan Kinerja Mahasiswa dan Efisiensi Penggunaan Daya Listrik di Bengkel Kayu Politeknik Negeri Bali. Disertasi. Program Pascasarjana Universitas Udayana Bali.

Sutajaya, I M. Ristiati, N.P, Setiabudi, G. I. 2009. Penerapan Ergonomi Berbasis Kearifan Lokal untuk Meningkatkan Kualitas Kesehatan dan Produktivitas Pekerja di Industri Kecil. Laporan Penelitan Strategis Nasional. Jurusan Pendidikan Biologi. F MIPA. UNDIKSHA.

Sutajaya, I M., \& Ristiati, N.P. 2011. Perbaikan Kondisi Kerja Berbasis Kearifan Lokal yang Relevan dengan Konsep Ergonomi untuk Meningkatkan Kualitas Kesehatan dan Produktivitas Pematung di Desa Peliatan Ubud Gianyar. Jurnal Penelitian dan Pengembangan Sains dan Humaniora ISSN 1979-7095. Volume 5, No.3, Desember 2011.

Sutajaya, I M. \& Gunamantha, I M. 2014. Pemberdayaan Masyarakat Melalui Usaha Kuliner Lokal untuk Mengembangkan

Sikap
Kewirausahaan dan Meningkatkan Pendapatan Pedagang Kaki Lima di Desa Peliatan, Ubud, Gianyar. Laporan Penelitian. Universitas Pendidikan Ganesha.

Sutarja, I N. 2012. Redesain Berbasis Ergonomi dan Kearifan Lokal Meningkatkan Efisiensi Energi Listrik dan Kualitas Hidup Penghuni pad Rumah Tradisional di Desa Pengotan. Disertasi. Program Pascasarjana Universitas Udayana Bali.

Sutjana, I D.P. Sutajaya, I M., Purnawati, S. Adiamika, P, Tunas, K. Suardana, E, \& Swamardika, I.B.A. 2008 Preliminary Anthropometric Data of Medical Students for Equipment Applications. Journal of Human Ergology Vol. 37. No 1.: $45-48$.

Wijaya, I P.G. 2012. Penerapan Manajemen Kinerja Klinik Berbasis Tri Hita Karana pada Kepuasan Kerja Komitmen Kerja dan Locus of Control terhadap Peningkatan Kinerja Pegawai dan Bidan di Unit Rawat Inap Rumah Sakit Umum Bangli. Disertasi. Program Pascasarjana Universitas Udayana Bali.

Wikipedia, 2012. Kewirausahaan. [Cited 2012 September 10] Available at http://id.wikipedia.org/wiki/Kewirau sahaan

Yuliyaningsih I.P, Susilaningsih, dan Jaryanto. 2013. Hubungan Pengetahuan Kewirausahaan dan Persepsi Peluang Kerja di Bidang Akuntansi dengan Minat Berwirausaha. Jupe-Jurnal Pendidikan Ekonomi Vol 2, No .1. 